\title{
Organizacja nadzoru nad systemem finansowym w Polsce
}

Streszczenie: Celem artykułu jest analiza działalności podmiotów nadzorujących polski system finansowy. Opracowanie rozpoczynają rozważania dotyczące istoty nadzoru nad systemem finansowym. W dalszej kolejności przedstawione są zagadnienia związane z ewolucją nadzoru finansowego w Polsce po 1989 r. Funkcjonowanie Komisji Nadzoru Finansowego jako podmiotu odpowiedzialnego za nadzór mikroostrożnościowy oraz Komitetu Stabilności Finansowej realizującego nadzór makroostrożnościowy stanowią kolejne zagadnienia opracowania. W zakończeniu autor odnosi się do przedstawionej we wstępie hipotezy i przedstawia końcowe wnioski.

Słowa kluczowe: system finansowy, nadzór mikroostrożnościowy, nadzór makroostrożnościowy, instytucje finansowe

\section{Wstęp}

Sprawnie funkcjonujący system finansowy przyczynia się do prawidłowego rozwoju gospodarki w aspekcie wewnętrznym i zewnętrznym. Pierwszy aspekt traktowany jest jako zdolność tego systemu do jej finansowania, natomiast wypracowanie umiejętności przeciwstawiania się kryzysom dotyczy kolejnego. Zasadnym zatem wydaje się podjęcie rozważań nad funkcjonowaniem nadzoru nad systemem finansowym w związku z jego znaczeniem dla gospodarki. Pełni on istotną rolę w systemie instytucjonalnym państwa. $Z$ takim rozwiązaniem mamy również do czynienia w Polsce. Interesującym zatem może okazać się zagadnienie dotyczące organizacji nadzoru nad systemem finansowym w Polsce.

Celem opracowania jest analiza działalności podmiotów nadzorujących polski system finansowy. Działania Komisji Nadzoru Finansowego (KNF) oraz Narodowego Banku Polskiego (NBP) w znacznej mierze przyczyniły się do skutecznego zabezpieczenia polskiego systemu finansowego przed ostatnim kryzysem finansowym, który znacząco dotknął 
Unię Europejską. Nadzór nad systemem finansowym został uzupełniony przez Komitet Stabilności Finansowej. Osiagnięcie przedstawionego celu wymaga zastosowania adekwatnych metod badawczych. Dla przeprowadzenia rozważań wykorzystano metody: historyczna, systemową i instytucjonalno-prawną. Metoda historyczna pozwoliła na zbadanie ewolucji procesu tworzenia się nadzoru nad systemem finansowym w Polsce po 1989 r. Umożliwiła przedstawienie konsolidacji tego nadzoru w jedną instytucję, jaką jest Komisja Nadzoru Finansowego. Metoda systemowa przyczyniła się do przedstawienia nadzoru nad wewnętrznie zintegrowanym, wyróżniającym się z otoczenia i kierującym się swoimi prawidłami systemem finansowym w Polsce. Każdy bowiem system finansowy posiada swoją specyfikę ze względu na stopień jego rozwoju. Zależy on od uwarunkowań politycznych, gospodarczych czy społecznych. Kolejną metodą badawczą wykorzystaną w opracowaniu jest metoda instytucjonalno-prawna. Przyczyniła się ona do wyjaśnienia działania podmiotów nadzorujących polski system finansowy, jakimi są Komisja Nadzoru Finansowego odpowiedzialna za nadzór mikroostrożnościowy i powołany do życia Komitet Stabilności Finansowej sprawujący nadzór makroostrożnościowy. Pozwoliła ona na zakreślenie badań do sfery przepisów prawnych związanych z funkcjonowaniem nadzoru finansowego w Polsce.

Hipoteza badania jest następująca: Przez działania instytucjonalnoprawne następuje wzrost znaczenia podmiotów sprawujących nadzór nad systemem finansowym w Polsce, dlatego, że:

- przyczyniały się one do stabilizacji systemu finansowego od początku tworzenia gospodarki rynkowej;

- status prawny Komisji Nadzoru Finansowego stanowi wzmocnienie dla jej działań;

- przez realizację swoich funkcji Komisja Nadzoru Finansowego przyczyniła się do ochrony systemu finansowego przed kryzysem;

- nadzór finansowy został wzmocniony przez wprowadzenie nadzoru makroostrożnościowego.

Pytania badawcze służące weryfikacji hipotezy to: Czy instytucje nadzoru przyczyniały się do stabilizacji systemu finansowego? Jaki jest status prawny Komisji Nadzoru Finansowego? Czy stanowi on wzmocnienie dla działań Komitetu? Jak realizacja funkcji KNF przyczyniła się do ochrony systemu finansowego przed kryzysem? Czy wprowadzenie nadzoru makroostrożnościowego stanowi wzmocnienie nadzoru finansowego? 


\section{Istota nadzoru nad systemem finansowym}

System finansowy to środek łączący różne sfery gospodarowania. Można go porównać do „krwiobiegu” zasilającego organizm człowieka. Realizując swoje funkcje dociera do wszystkich elementów systemu gospodarczego, przyczyniając się w ten sposób do zapewnienia równowagi całości. Dokonuje tego przez wykorzystanie nadwyżek kapitałowych i zaspokojenie występujących deficytów. W tym celu system finansowy wykorzystuje odpowiednie rynki, instytucje czy instrumenty (Kulikowska, 2003 , s. 35). Do podstawowych funkcji systemu finansowego zaliczamy funkcję monetarną (pieniężna), funkcję kapitałowo-redystrybucyjną oraz funkcję kontrolną. Funkcja pieniężna sprowadza się do dostarczenia i umożliwienia obiegu pieniądza w gospodarce. Umożliwienie przepływu wolnych środków pieniężnych od podmiotów, które nimi dysponują do podmiotów potrzebujących tej nadwyżki, realizowane jest przez funkcję kapitałowo-redystrybucyjną. Funkcja kontrolna polega zaś na kontrolowaniu przepływu strumieni pieniężnych. Funkcje te są ze sobą ściśle powiązane. Dwie ostatnie dotyczą bowiem tych samych procesów widzianych z dwóch różnych stron: funkcja kapitałowo-redystrybucyjna ujmuje to w ujęciu ex ante, a kontrolna ex post (Pietrzak, Polański, Woźniak, 2016, s. 18-19).

Wyróżniamy dwa główne systemy finansowe. Pierwszy system anglosaski (anglo-amerykański, rynkowy) oparty jest na rynku. Natomiast kontynentalny (reński, niemiecko-japoński) jest zorientowany bankowo. Podstawowa różnica między tymi systemami wynika $\mathrm{z}$ dominacji jednej $\mathrm{z}$ instytucjonalnych form występujących w systemie finansowym. W systemie anglosaskim występuje przewaga udziału rynku finansowego, a w systemie kontynentalnym dominującą formą instytucjonalną są banki. Taki podział systemu finansowego doprowadził do powstania odmiennych modeli bankowości. Wykształcił się model specjalistyczny związany z systemem anglosaskim i model uniwersalny charakterystyczny dla systemu kontynentalnego. W aspekcie instytucjonalno-strukturalnym modele te różnią się między sobą odmiennym zakresem czynności sprawowanym przez banki. Różnice w aspekcie funkcjonalnym między tymi systemami dotyczą zakresu mechanizmów, metod oraz podmiotów zaangażowanych $\mathrm{w}$ realizację poszczególnych funkcji systemu finansowego (Matysek-Jędrych, 2007, s. 93-96). Ze względu na pełnienie istotnych funkcji, system finansowy powinien być poddany nadzorowi państwa celem uniknięcia kryzysów. Nadmierne oderwanie się sektora finansowego 
od sektora rzeczowego wywołało zakłócenia w jego funkcjonowaniu, powodując w 2007 r. światowy kryzys.

System finansowy w gospodarce wolnorynkowej to mechanizm polegający na współtworzeniu i przepływie siły nabywczej między niefinansowymi podmiotami gospodarczymi. Składa się on z instrumentów finansowych, rynków finansowych, instytucji finansowych oraz zasad określających sposób ich funkcjonowania (Pietrzak, Polański, 2000, s. 11).

W polskim ustawodawstwie pojęcia kontrola i nadzór są zróżnicowane. Zostały one zaczerpnięte z terminologii nauk o zarządzaniu. Należy zatem odróżniać od siebie te pojęcia. Błędem jest używanie tych pojęć zamiennie. Pojęcie kontroli używane jest dla określenia funkcji organu polegającej na sprawdzeniu działalności innych jednostek, bez stałych możliwości wpływania na działalność jednostek kontrolowanych poprzez wydawanie wiążących nakazów lub poleceń (Wierzbowski, 2015, s. 79-80). Kontrola polega na badaniu stanu istniejącego i porównywaniu go ze stanem pożądanym, z możliwością oceny działań kontrolowanego i ich skutków, ale bez możliwości władczego oddziaływania na organ podległy (Lipowicz, 2015, s. 86). Kontrolujący obserwuje i rozpoznaje sytuację i na tej podstawie przedstawia wyniki organowi nadrzędnemu. Nie odpowiada jednak za działalność tego podmiotu (Daniluk, 1996, s. 12). Najczęstsze kryteria kontroli to:

- kryterium legalności polega na kontroli pod względem zgodności z przepisami prawnymi;

- kryterium celowości, czyli zgodności działalności z przyporządkowanymi zadaniami do realizacji określonych celów;

- kryterium rzetelności związane jest z wypełnianiem w sposób staranny, sumienny i terminowy nałożonych obowiązków;

- kryterium gospodarności polegające na kontroli wydajnego i oszczędnego wykorzystania zasobów (Buczyński, 2002, s. 7-8).

Nadzór to pojęcie szersze od pojęcia kontroli. W przypadku nadzoru jego organ jest wyposażony w środki oddziaływania na postępowanie organów czy instytucji nadzorowanych (Wierzbowski, 2015, s. 80). Nadzorujący obserwuje i dokonuje ocen, ale również odpowiada za wyniki działalności podmiotu nadzorowanego. Należy jednak zaznaczyć, że odpowiedzialność ta jest ograniczona do sfery, w zakresie której dysponuje on skutecznymi środkami przymusu. W takiej sytuacji nadzór zawsze obejmuje kontrolę, natomiast wykonywanie kontroli nie musi się łączyć z możliwością stosowania środków nadzorczych. W Polsce najlepiej od- 
zwierciedla opisane wyżej relacje Najwyższa Izba Kontroli i Komisja Nadzoru Finansowego (Daniluk, 1996, s. 12).

Nadzór należy sprawować w oparciu o zasadę praworządności ${ }^{1}$ mówiąca, że organy nadzoru działają zawsze na podstawie i w granicach prawa zgodnie z Konstytucją RP (Konstytucja RP 1997, art. 7). W sensie normatywnym realizacja tej zasady oznacza działania instytucji publicznych w granicach kompetencji przyznawanych przez normy prawne.

Podstawowym celem nadzoru nad systemem finansowym jest kontrola ryzyka podejmowanego przez instytucje finansowe, przede wszystkim przez banki komercyjne. Instytucje realizujące nadzór koncentrują się na etapie zapobiegania destabilizacji na rynku finansowym.

Przyczyną regulacji na rynku finansowym jest fakt, że deponenci mają ograniczoną siłę rynkową ze względu na duże ich rozproszenie, z drugiej strony, są poddani monopolistycznym zachowaniom banków komercyjnych. Występuje również niedoskonała informacja po ich stronie, co ma wpływ na brak możliwości monitorowania przez nich działalności tych banków. Może to doprowadzić do runu na banki i doprowadzić do zagrożenia systemowego (Matthews, Thompson, 2007, s. 189). Podstawą nadzoru finansowego jest zapewnienie stabilności systemu finansowego. $\mathrm{W}$ związku z tym, powinien być pełniony na trzech poziomach: mikroostrożnościowym, makroostrożnościowym oraz zapewnienie ochrony konsumentom (Hryckiewicz, Pawłowska, 2013, s. 8).

Wyróżniamy dwie podstawowe formy nadzoru nad rynkiem finansowym: system sektorowy i system zintegrowany (Goodhardt, 2000). Kryterium tego podziału jest zakres ingerencji nadzoru nad poszczególnymi segmentami systemu finansowego. System sektorowy (wieloinstytucjonalny) charakteryzuje się tym, że każdy sektor rynku finansowego: bankowy, kapitałowy oraz ubezpieczeń i emerytalny ma swój oddzielny organ nadzorczy. Występuje on na Litwie, w Grecji, Francji, Portugalii i we Włoszech. Powodem stosowania tego systemu była niska przenikalność rynków fi-

${ }^{1}$ Zasada praworządności jest jedną z naczelnych zasad zawartych w Konstytucji RP. Wynika ona bezpośrednio z art. 2 Konstytucji RP, który mówi, że Rzeczpospolita Polska jest demokratycznym państwem prawnym, urzeczywistniającym zasady sprawiedliwości społecznej. Ma ona odzwierciedlenie w innych aktach prawnych. Naczelne zasady konstytucyjne są normami prawnymi charakteryzującymi się szczególną doniosłością, ponieważ z nich wynikają inne normy oraz określają cechy danej instytucji. Do zasad tych zaliczamy również: zasadę demokratycznego państwa prawnego, zasadę zwierzchnictwa narodu, zasadę podziału i równowagi władz, zasadę społecznej gospodarki rynkowej, zasadę pluralizmu politycznego, zasadę subsydialności. 
nansowych pomiędzy sobą. Taki rodzaj nadzoru był popularny w latach 90-tych. W tym czasie każdy z rynków finansowych miał swoją specyfikę.

System zintegrowany (jednoinstytucjonalny) jest zorganizowany w oparciu o jednego nadzorcę (mega nadzorca) sprawującego nadzór nad całym rynkiem finansowym. Na taki krok zdecydowało się ponad 30 państw. Procesowi tworzenia systemu zintegrowanego towarzyszyło wyodrębnienie nadzoru mikroostrożnościowego nad sektorem bankowym z banku centralnego. Większość państw Europy Środkowej i Wschodniej postanowiło wprowadzić pojedynczą instytucję nadzorującą cały rynek finansowy (Hryckiewicz, Pawłowska, 2013, s. 11-12). Tendencja ta jednak została w 2002 r. zahamowana, a na jej miejsce pojawił się model, w którym nadzór nad instytucjami finansowymi jest skupiony w banku centralnym, takie zmiany zapoczątkowała Holandia.

\section{Ewolucja nadzoru finansowego w Polsce po 1989 r.}

Powstały po 1989 r. system finansowy uwidocznił potrzebę utworzenia instytucji, które sprawowałyby nadzór nad nim. Ustawy, jakie wprowadzono po 1989 r. w bankowości, dały podstawy do wyłonienia z 9 oddziałów okręgowych NBP banków komercyjnych (Kraś, 2013, s. 60). Stały się one zaczątkiem tworzącego się systemu finansowego w polskiej gospodarce wolnorynkowej. Dysponowały kapitałem i niewielką ilością zgromadzonych wkładów. W związku z rozwojem banków komercyjnych, należało wprowadzić nad nimi nadzór. Został on powierzony Narodowemu Bankowi Polskiemu (NBP). Do realizacji zadań dotyczących sprawowania nadzoru nad działalnością banków komercyjnych powołano w 1989 r. w strukturze NBP Departament Nadzoru Bankowego. Jego nazwa uległa zmianie w 1990 r. na Generalny Inspektorat Nadzoru Bankowego (GINB) (Nadzór, 2007, s. 8). Podstawowe cele nadzoru bankowego zawarto w ustawie Prawo bankowe i były one realizowane przez Prezesa NBP. Zatem nadzór nad systemem bankowym był sprawowany przez jednoosobowy organ banku centralnego w Polsce. Prezes NBP został wyposażony w ogromną władzę. W tym czasie sprawowany nadzór miał wymiar funkcjonalny i był realizowany obok innych funkcji NBP (Fojcik-Mastalska, 2009, s. 33-39). Kolejny etap ewolucji nadzoru dotyczył wyłączenia Prezesa NBP z jego kompetencji. Został on powierzony od stycznia 1998 r. Komisji Nadzoru Bankowego (KNB). Nastapiło zatem przekazanie nadzoru $\mathrm{z}$ rąk jednoosobowego organu do organu 
kolegialnego. Prezes NBP został przewodniczącym KNB. W ten sposób całkowicie nie zmarginalizowano Prezesa NBP w nadzorze. Jego pozycja nadal była znacząca. W przypadku równej ilości głosów, jego głos był rozstrzygający. Miał on również prawo do powoływania i odwoływania w uzgodnieniu z Ministrem Finansów (MF), Generalnego Inspektora Nadzoru Bankowego (Ustawa z dnia 29 sierpnia 1997 r. o Narodowym..., art. 25 ust. 2 tekst ogłoszony).

W roku 1991 powstaje kolejna instytucja nadzorująca polski system finansowy, a jest nią Komisja Papierów Wartościowych (KPW). Zostaje ona przekształcona w Komisję Papierów Wartościowych i Giełd (KPWiG). W 1996 r. powołano do życia Państwowy Urząd Nadzoru Ubezpieczeniowego (PUNU). Nadzorował on działalność zakładów ubezpieczeniowych i brokerów. Dwa lata później powstaje Urząd Nadzoru nad Funduszami Emerytalnymi (UNFE). Powstanie w 2002 r. Komisji Nadzoru Ubezpieczeń i Funduszy Emerytalnych powoduje likwidację PUNU i UNFE. Dalszym etapem konsolidacji nadzoru w polskim systemie finansowym było połączenie Komisji Nadzoru Ubezpieczeń i Funduszy Emerytalnych z Komisją Papierów Wartościowych i Giełd. Efektem tych połączeń było powołanie w 2006 r. Komisji Nadzoru Finansowego (KNF) (Ustawa z dnia 21 lipca 2006 r. o nadzorze..., art. 3, ust. 1). Zakończyło ono etap scalania instytucji nadzoru nad systemem finansowym.

Do 2002 r. w Polsce występował nadzór sektorowy. Każdy sektor rynku finansowego miał swojego nadzorcę. Trudno jednoznacznie odpowiedzieć jakimi przesłankami kierował się ustawodawca integrujące nadzór nad systemem finansowym w Polsce. Można rozważyć trzy kwestie. Pierwsza to podążanie za moda, jaka miała miejsce w tym czasie w Europie. Czy może był to świadomy zabieg związany ze słabą efektywnością działania nadzoru finansowego w Polsce (Nadolska, 2014, s. 198), w związku z wzajemnym przenikaniem się rynków, a może decyzja polityczna mająca na celu osłabienie pozycji ówczesnego Prezesa NBP. Włączenie w 2008 r. do kompetencji KNF nadzoru nad systemem bankowym było kolejnym etapem tworzenia nadzoru zintegrowanego.

Następny etap integracji nadzoru dotyczył włączenia kolejnych podmiotów. W dniu 27 października 2012 r. nadzór KNF poszerzono o Spółdzielcze Kasy Oszczędnościowo-Kredytowe (SKOK). Obecnie należałoby zastanowić się nad dalszym podmiotowym poszerzeniem nadzoru chociażby o kontrowersyjne instytucje parabankowe. Inną kwestią, jaka może wystapić, jest zmiana modelu nadzoru nad rynkiem finansowym, lecz to wydaje się mało prawdopodobne. 


\section{Nadzór mikroostrożnościowy}

Nadzór mikroostrożnościowy nad rynkiem finansowym, który jest istotnym elementem systemu finansowego w Polsce sprawuje Komisja Nadzoru Finansowego. Jej zadaniem jest monitowanie pojedynczych podmiotów w systemie finansowym. Przez takie działania chroni również cały system finansowy. Może bowiem w przypadku złego działania jednej instytucji wystąpić zagrożenie dla stabilności całego systemu finansowego, co spowoduje spadek dla jego zaufania (Szczepańska, Sotomska-Krzysztofik, 2004, s. 11).

Komisja Nadzoru Finansowego została powołana zgodnie z ustawą o nadzorze nad rynkiem finansowym (Ustawa z dnia 21 lipca 2006 r. o nadzorze). Powstał zatem kolegialny organ właściwy w sprawach nadzoru nad rynkiem finansowym odpowiadający rozwiązaniom prezentowanym w opinii Europejskiego Banku Centralnego. Mimo, że w ustawie nie określono charakteru organu, jakim jest KNF (Projekt rządowy ustawy o nadzorze nad rynkiem finansowym wraz..., 2006), zalicza się ją do organów administracji publicznej. Spełnia ona warunki, jakie zostały przyjęte przez naukę prawa administracyjnego: wyodrębnienie organizacyjne części aparatu administracji publicznej, działanie w imieniu i na rachunek państwa, uprawnienie do stosowania środków władczych, wykonywanie zadań publicznych z zakresu administracji oraz działanie w ramach przyznanych przez prawo kompetencji (Nadolska, 2011, s. 133). Zgodność co do statusu KNF jako organu administracji publicznej potwierdza opinia prof. Chłopeckiego. Stwierdził on, że ,to raczej Komisja Papierów Wartościowych i Giełd oraz Komisja Nadzoru Ubezpieczeniowego i Funduszy Emerytalnych powinny zostać wyłączone ze struktur administracji rządowej, nie zaś Komisja Nadzoru Bankowego i Generalny Inspektorat Nadzoru do tej administracji włączone" (Biuro Analiz Sejmowych, opinia zlecona o..., 2006).

Koncepcję organu administracji publicznej należy oprzeć na rozwiązaniach zastosowanych w prawie, przede wszystkim Konstytucji RP oraz przepisach prawa ustrojowego. Rozwiązania ustrojowe zawarte w Konstytucji i przepisach prawa ustrojowego wskazują na oparcie konstrukcji administracji publicznej na koncepcji organizacyjno-przedmiotowej. Związane jest to z rozdziałem dwóch regulacji: regulacji organów w ujęciu organizacyjno-przedmiotowym oraz odrębnej regulacji powołania składu osobowego. W ustawie o nadzorze nad rynkiem finansowym zastosowano właśnie takie rozwiązanie (Nadolska, 2011, s. 133). 
W 2010 r. odbyła się ogólnopolska konferencja naukowa poświęcona statusowi prawnemu i zadaniom nadzoru finansowego w Polsce (Ogólnopolska Konferencja Naukowa, 2010, s. 1). Przedstawiciele środowiska naukowego uznali, że KNF jest organem administracji publicznej, jednakże nie jest organem administracji rządowej. Za powyższym twierdzeniem przemawiają między innymi takie przesłanki jak: apolityczny charakter nadzoru finansowego, kadencyjność Przewodniczącego KNF z możliwością odwołania tylko w ściśle określonych w ustawie przypadkach, brak wskazania zakresu własności KNF w ustawie o działach administracji rządowej, brak władczych instrumentów ingerowania w pracę KNF.

W dyskusjach na temat statusu prawnego KNF pojawiają się również odmienne poglądy co do tego, że KNF to organ administracji publicznej. Prezes Rady Ministrów (PRM) uznał bowiem Komisję za organ administracji rządowej (Rządowy projekt ustawy o nadzorze nad rynkiem finansowym..., 2006). Podobnego zdania był Rzecznik Praw Obywatelskich (RPO), wskazując we wniosku do Trybunału Konstytucyjnego, że KNF należy zaliczyć do organów administracji rządowej (Wyrok TK z dnia 21 czerwca 2011 r. $w$ sprawie statusu pracowników..., nr 5A/2011). Uznał on bowiem, że należy ustalić co oznacza pojęcie ,administracja rządowa”. Brak określenia w ustawie, że KNF jest centralnym organem administracji rządowej nie przesądza o jej wyłączeniu z tej kategorii organów. Ostatecznie RPO uznał, że ma miejsce dość intensywne powiązanie Komisji z naczelnym organem administracji rządowej. Nadzór PRM nad innymi organami określonymi w ustawach jako centralne organy administracji rządowej jest ujęty tak samo lub w sposób zbliżony do nadzoru nad KNF. Argumentem za uznaniem KNF jako organu administracji rządowej przemawia okoliczność, że Komisja Papierów Wartościowych i Giełd oraz Komisja Nadzoru Ubezpieczeń i Funduszy Emerytalnych przejęte przez KNF wykonywały wcześniej funkcje nadzorcze nad rynkiem finansowym jako organy administracji rządowej.

Nadzór nad działalnością KNF sprawuje Prezes Rady Ministrów (PRM). W skład Komisji wchodzą Przewodniczący, dwóch zastępców i czterech członków, którymi są: minister finansów albo jego przedstawiciel, minister rodziny, pracy i polityki społecznej albo jego przedstawiciel, Prezes Narodowego Banku Polskiego bądź jego Wiceprezes, przedstawiciel Prezydenta Rzeczpospolitej. Przewodniczący Komisji powoływany jest przez PRM na okres pięciu lat. Kandydat na Przewodniczącego musi spełniać określone w ustawie wymogi. Wskazuje ona również sytuacje w których PRM może odwołać Przewodniczącego Komisji. Zastępców 
Przewodniczącego powołuje i odwołuje PRM na wniosek Przewodniczącego Komisji. Komisja i Przewodniczący wykonują zadania przy pomocy Urzędu Komisji Nadzoru Finansowego (UKNF) (Ustawa z dnia 21 lipca 2006 r. o nadzorze..., Rozdział 2).

Do podstawowych funkcji realizowanych przez KNF zaliczamy: funkcję licencyjną, funkcję regulacyjna, funkcję kontrolną i funkcję dyscyplinująca. Funkcja licencyjna polega na dopuszczaniu instytucji finansowych do prowadzenia działalności po spełnieniu określonych warunków. Jest to szczególnie ważne ze względu na status instytucji zaufania publicznego. Funkcja regulacyjna polega na oddziaływaniu KNF na zachowania instytucji finansowych w celu określenia minimalnych standardów bezpieczeństwa. Zadaniem funkcji kontrolnej jest przeprowadzanie analiz oraz identyfikowanie zagrożeń, jakie mogą się pojawić w związku z działaniem instytucji finansowych. W ramach tej funkcji dokonuje się kontroli przestrzegania obowiązujących regulacji w systemie finansowym. Funkcja dyscyplinująca polega na nakładaniu sankcji na instytucje finansowe oraz konkretne osoby odpowiadające za nieprawidłowości zgodnie z przyjętą ustawą.

KNF podejmuje uchwały, w tym decyzje administracyjne i postanowienia, określone w przepisach ogólnych. Decyzja co do uchwały podejmowana jest zwykłą większością głosów w obecności co najmniej 4 osób, w tym Przewodniczący lub zastępca. Przy równej liczbie głosów decyduje głos Przewodniczącego. KNF prowadzi nadzór w odniesieniu do rynku finansowego, co oznacza wymogi posługiwania się aktami generalnymi, czyli powszechnego zastosowania (zewnętrznymi). Występuje zatem pewna sprzeczność co do zgodności z prawem wydawania uchwał o charakterze zewnętrznym przez Komisję. KNF wydaje uchwały w odniesieniu do banków formalnie niemające charakteru powszechnie obowiązujących źródeł prawa. Konstytucja RP precyzuje kto może wydawać uchwały Prezydent RP, Rada Ministrów, Prezes RM, ministrowie kierujący działami administracji rządowej oraz Krajowa Rada Radiofonii i Telewizji (KRRiT), (Konstytucja RP z dnia 2 kwietnia 1997) w tym gronie nie ma KNF. Podobny charakter mają wydawane przez KNF rekomendacje.

\section{Nadzór makroostrożnościowy}

Nadzór makroostrożnościowy stanowi wypełnienie luki, jaka ujawniła się podczas kryzysu zapoczątkowanego w 2007 r. Pokazała ona, że 
sprawny nadzór mikrostrożnościowy i polityka pieniężna nie wystarczają do zachowania stabilności finansowej. Na szczeblu UE w 2011 r. powstała Europejska Rada Ryzyka Systemowego (ERRS), której zadaniem jest postrzeganie systemu finansowego jako całości w celu identyfikacji i podejmowania działań zmieniających ryzyko systemowe. W Polsce, zgodnie z zaleceniami ERRS, podjęto działania mające na celu wypełnienie luki, jaką uwidocznił kryzys. Dyskusja nad projektem ustawy o nadzorze makroostrożnościowym rozpoczęła się w 2013 r. Pierwsze propozycje przewidywały powołanie Rady ds. Ryzyka Systemowego jako kolegialnej instytucji działającej poza strukturami banku centralnego (Projekt ustawy o nadzorze makroostrożnościowym z dnia 3 stycznia 2014 r.; Projekt ustawy o nadzorze makroostrożnościowym z dnia 23 kwietnia 2014). Jednocześnie zapewniały one bankowi centralnemu wiodącą rolę w nadzorze makroostrożnościowym oraz niezależność podczas jego realizacji. W związku z tym organ makroostrożnościowy powinien być niezależny co najmniej w sensie operacyjnym od ciał politycznych i sektora finansowego. Zrealizowano również postulat kolegialności mówiący, że organem prowadzącym politykę makroostrożnościową może być jedna instytucja lub rada złożona $\mathrm{z}$ instytucji, których działania mają istotny wpływ na stabilność finansową (Zalecenie Europejskiej Rady ds. Ryzyka Systemowego z dnia 22 grudnia 2011 r. $w$ sprawie...). Zgodnie z projektem ustawy z 23 kwietnia 2014 r. w skład RRS wchodził Prezes NBP jako Przewodniczący, minister właściwy do spraw instytucji finansowych, Przewodniczący Komisji Nadzoru Finansowego oraz Prezes Zarządu Bankowego Funduszu Gwarancyjnego. Uchwały Rady podejmowane miały być w głosowaniu jawnym, większością głosów, przy obecności co najmniej trzech członków, w tym Przewodniczącego, czyli Prezesa NBP. W przypadku równej liczby głosów decydował głos Przewodniczącego Rady. Tym samym NBP miał zagwarantowaną wiodącą rolę w Radzie. Omawiany projekt ustawy uwzględniał opinię Europejskiego Banku Centralnego (EBC) (Opinia Europejskiego Banku Centralnego z dnia 18 lutego 2014 r. w sprawie nadzoru ...) wskazującą na likwidację funkcji wiceprzewodniczącego przewidzianą w projekcie z 3 stycznia 2014 r. Ostatecznie jednak nie powołano Rady ds. Ryzyka Systemowego, a jej zadania zostały przekazane Komitetowi Stabilności Finansowej (Ustawa z dnia 5 sierpnia 2015 r. o nadzorze makroostrożnościowym...). W przypadku powołania tej instytucji zapewniono zgodność z zaleceniami ERRS co do tego, że nadzór makroostrożnościowy będzie sprawował organ kolegialny poza strukturami banku centralnego, nie zapewniono jednak wiodącej roli NBP. 
Do momentu uchwalenia ustawy o nadzorze makroostrożnościowym nad systemem finansowym i zarządzaniu kryzysowym w systemie finansowym KSF był odpowiedzialny za działania związane z zarządzaniem kryzysowym. Uchwalona ustawa wprowadziła istotne zmiany związane z wiodąca rolą NBP. Z tytułu ustawy wynika, że będzie on realizował dwa cele: nadzoru makroostrożnościowego i zarządzania kryzysowego, choć ten ostatni jest przypisany ministrowi finansów. W celu uniknięcia rozmycia odpowiedzialności i skuteczności ich realizacji należałoby je rozdzielić, jak proponowały to poprzednie projekty ustaw.

Członkami KSF są: Minister Finansów, Prezes Narodowego Banku Polskiego, Przewodniczący Komisji Nadzoru Finansowego oraz Prezes Zarządu Bankowego Funduszu Gwarancyjnego. Przewodniczącym Komitetu w zależności od realizacji zadań jest Prezes NBP, jeżeli chodzi o nadzór makoroostrożnosciowy lub Minister Finansów, jeżeli chodzi o zadania w zakresie zarządzania kryzysowego. W posiedzeniach KSF członkowie uczestniczą osobiście. W sytuacji, gdy nie jest możliwy osobisty udział w posiedzeniu przewodniczącego Komitetu, wyznaczają oni swoich przedstawicieli, którym podczas posiedzenia przysługują uprawnienia odpowiednio reprezentowanego przewodniczącego. W posiedzeniach KSF mogą również uczestniczyć doradcy posiadający odpowiednią wiedzę lub doświadczenie w zakresie zagadnień objętych zadaniami Komitetu. Posiedzenia są zwoływane przez przewodniczącego właściwego w realizacji zadań Komitetu albo przez wyznaczonego przez niego przedstawiciela. W celu realizacji zadań Komitet podejmuje uchwały. Są one podejmowane w głosowaniu jawnym większością głosów, w obecności co najmniej trzech członków Komitetu, w tym przewodniczącego. W przypadku równej liczby głosów decyduje głos przewodniczącego. Przewodniczący KSF przedstawia Sejmowi roczną informację o działalności Komitetu do dnia 31 lipca roku następującego po roku, którego dotyczy informacja (Ustawa z dnia 5 sierpnia 2015 r. o nadzorze makroostrożnościowym..., Rozdział 2).

Przewagę w składzie KSF posiada rząd. Wynika to ze sposobu powoływania Przewodniczącego KNF i Prezesa BFG. Przewodniczącego KNF powołuje Prezes Rady Ministrów na pięcioletnią kadencję. Może on pełnić swoją funkcję bez ograniczeń związanych z kadencyjnością. Przyczynia się to do zmniejszenia jego niezależności w przypadku zdobywania sobie przychylności Prezesa RM w związku z ponownym wyborem.

Analiza ustawy pokazuje, że występuje możliwość oddziaływania na system finansowy w zakresie prowadzenia nadzoru makroostrożnościo- 
wego przez przedstawianie stanowisk i wydawanie rekomendacji. Brak natomiast uprawnień decyzyjnych KSF co do zastosowania instrumentów makroostrożnościowych. W takiej sytuacji Komitet będzie jedynie organem opiniotwórczym.

Ustawodawstwo polskie, podobnie jak w przypadku KNF, nie daje podstaw prawnych do wydawania uchwał przez KSF jako aktów mających charakter powszechnie obowiązujących źródeł prawa. KSF jako podmiot prowadzący nadzór makroostrożnościowy swoje uchwały będzie kierował do podmiotów znajdujących się w systemie finansowym. W takim przypadku nie ma pewności czy Trybunał Konstytucyjny nie zakwestionuje tych uchwał. Z podobną sytuacją mieliśmy do czynienia w przypadku organów NBP. Tam Trybunał Konstytucyjny uznał, że wiodąca rola NBP jako banku banków powoduje, że mimo samodzielności i formalnej niezależności banków komercyjnych, w zakresie polityki pieniężnej są one poddane zależności, pozwalającej na określenie jej jako podległość funkcjonalna. W takiej sytuacji, zdaniem TK, podległość organizacyjna powinna być rozumiana szerzej i obejmować podległość funkcjonalną. Jednak takie szerokie rozumienie podległości przez TK mogłoby doprowadzić do rozchwiania konstytucyjnej koncepcji prawa wewnętrznego. Interpretację tę ograniczono zatem do specyficznej pozycji NBP, w której podmiotem jest konstytucyjna instytucja, jaką jest NBP, zaś przedmiotem konstytucyjnie określone jej zadania (Wyrok TK z dnia 28 czerwca 2000 r. prawo organów Narodowego..., nr 5/2000). Jednak podległość funkcjonalna NBP - banki komercyjne, jako odmiana podległości organizacyjnej wykreowana przez TK, w samej jego ocenie ma słabe podstawy prawne. Koncepcja podległości funkcjonalnej w relacji NBP - banki komercyjne została oparta na relacjach, jakie występują między Sejmem a Najwyższą Izbą Kontroli (NIK) (Wyrok z dnia 1 grudnia 1998 r. przepisy przyjmujace Marszatkowi..., nr 7/2000). Są to jednak zupełnie inne więzi o charakterze ustrojowym, określone przez Konstytucję RP.

\section{Zakończenie}

Przedstawiona we wstępie opracowania hipoteza mówiąca o tym, że przez działania instytucjonalno-prawne następuje wzrost znaczenia podmiotów sprawujących nadzór nad systemem finansowym w Polsce, dlatego, że: - przyczyniały się one do stabilizacji systemu finansowego od początku tworzenia gospodarki rynkowej; 
- status prawny Komisji Nadzoru Finansowego stanowi wzmocnienie dla jej działań;

- przez realizację swoich funkcji Komisja Nadzoru Finansowego przyczyniła się do ochrony systemu finansowego przed kryzysem;

- nadzór finansowy został wzmocniony przez wprowadzenie nadzoru makroostrożnościowego została zweryfikowana w zasadzie pozytywnie.

Nowo powstały system finansowy w Polsce po 1989 r., w początkowej fazie głównie opary o rozwój systemu bankowego wymagał nadzoru. Instytucje nadzorcze powstawały w celu regulacji nowo powstałych sektorów rynku finansowego. W początkowej fazie ze względu na niską przenikalność sektorów występował nadzór sektorowy. Jednak dalszy rozwój poszczególnych sektorów rynku finansowego doprowadził do większej ich przenikalności. Odpowiedzią na to była konsolidacja nadzoru w jedną instytucję, jaką jest Komisja Nadzoru Finansowego. Od samego początku instytucje nadzorujące rynek finansowy wpływały stabilizująco na jego działanie.

Status prawny Komisji Nadzoru Bankowego jako organu administracji publicznej a nie rządowej stwarza możliwości bardziej niezależnego nadzorowania rynku finansowego w Polsce. Ogranicza to w pewnym stopniu możliwość oddziaływania RM na ten organ.

Nadzór nad rynkiem finansowym wymagał również właściwej realizacji funkcji KNF. Realizowane przez KNF funkcje licencyjna, regulacyjna, kontrolna i dyscyplinująca przyczyniły się w sposób zasadniczy do ochrony polskiego systemu finansowego przed kryzysem. Szczególnego znaczenia nabrała funkcja regulacyjna polegająca na oddziaływaniu KNF na zachowania instytucji finansowych w celu określenia minimalnych standardów bezpieczeństwa. Wypracowany model nadzoru w Polsce powinien zatem stać się pewnym wzorem do naśladowania, szczególnie w aspekcie nadzorowania systemu bankowego, który w Europie został ciężko doświadczony przez kryzys. Duże zasługi w zachowaniu stabilności systemu bankowego poniósł również NBP, bowiem do końca 2007 r., czyli tuż przed rozpoczęciem kryzysu, nadzór nad nim sprawowała Komisja Nadzoru Bankowego działająca w strukturach NBP.

Istotnym uzupełnieniem nadzoru finansowego ujawnionym przez kryzys jest wprowadzenie nadzoru makroostrożnościowego. W Polsce organem odpowiedzialnym za ten nadzór jest Komitet Stabilności Finansowej. Celem działalności KSF będzie między innymi wzmacnianie odporności systemu finansowego na wypadek materializacji ryzyka sys- 
temowego i wspieranie w ten sposób długookresowego, zrównoważonego wzrostu gospodarczego. Nadzór makroostrożnościowy będzie oddziaływał na cały system finansowy, a nie jak to jest w przypadku nadzoru mikroostrożnosciowego sprawowanego przez KNF na poszczególne jego podmioty.

Pojawiają się również argumenty osłabiające hipotezę postawioną we wstępie. Czy włączenie KNB do KNF było przemyślanym działaniem ustawodawczym związanym z jej małą efektywnością działania? Wydaje się jednak, że KNB dobrze przygotowała system bankowy do kryzysu, jaki rozpoczął się w 2008 r. Może należało nadzór nad systemem bankowym pozostawić w kompetencji NBP, a nie ulegać trendom, jakie wówczas występowały w Europie.

Relacje, jakie występują między Prezesem RM a Przewodniczącym w procesie powoływania go na to stanowisko mogą osłabić samodzielność podejmowania decyzji. Jest on powoływany na okres pięciu lat bez możliwości ograniczenia kadencyjności, co może wpłynąć na podejmowanie decyzji przychylnych rządowi. Ponadto w siedmioosobowym składzie KNF zapewniono przewagę rządową. Jest w niej tylko dwóch przedstawicieli niezależnych tj. Prezes NBP i przedstawiciel Prezydenta RP.

$\mathrm{W}$ nadzorze makroostrożnościowym nie zapewniono, zgodnie z zaleceniami ERRS, wiodącej roli banku centralnego. Zbyt dużą rolę odgrywa czynnik rządowy. W Komitecie Stabilności Finansowej jest tak naprawdę jedna osoba niezależna od Prezesa RM, a jest nią Prezes NBP. Na powołanie pozostałych członków KSF, czyli Ministra Finansów, Przewodniczącego KNF oraz Prezesa Bankowego Funduszu Gwarancyjnego (BFG) w sposób bezpośredni lub pośredni ma wpływ Prezes RM. Złym rozwiązaniem jest również realizacja dwóch odmiennych celów przez ten organ.

Istotnym osłabieniem hipotezy może okazać się brak podstaw prawnych do wydawania uchwał przez KNF i KSF jako aktów mających charakter powszechnie obowiązujących źródeł prawa. KNF prowadzi nadzór mikroostrożnościowy i KSF sprawuje nadzór makroostrożnościowy w odniesieniu do rynku finansowego, co oznacza wymogi posługiwania się aktami generalnymi, czyli powszechnego zastosowania. W związku z tym występuje pewna sprzeczność co do zgodności z prawem wydawania uchwał o charakterze zewnętrznym przez KNF i KSF. W takim przypadku nie ma pewności czy Trybunał Konstytucyjny nie zakwestionuje ich uchwał. Polska Konstytucja określa zakres osób, które mogą wydawać akty powszechnego zastosowania. 
Należy zatem podjąć działania porządkujące przedstawione wyżej kwestie w celu dalszego wzmacniania pozycji organów nadzoru w polskim systemie finansowym. Pozostawienie tych kwestii bez właściwych działań może doprowadzić do zmniejszania znaczenia organów nadzoru finansowego $\mathrm{w}$ związku $\mathrm{z}$ możliwością pojawienia się zakłóceń $\mathrm{w}$ ich funkcjonowaniu.

\section{Bibliografia}

\section{Akty prawa:}

Zalecenie Europejskiej Rady ds. Ryzyka Systemowego z dnia 22 grudnia 2011 r. wsprawie mandatu makroostrożnościowego organów krajowych (ERRS/2011/3), Dz. U. UE 14.02.2012, C 41/1.

Konstytucja RP z dnia 2 kwietnia 1997 r., Dz. U. Nr 78, poz. 483 ze zm.

Ustawa z dnia 29 sierpnia 1997 r. o Narodowym Banku Polskim, Dz. U. Nr 140, poz. 938 , tekst ogłoszony.

Ustawa z dnia 21 lipca 2006 r. o nadzorze nad rynkiem finansowym, Dz. U. Nr 157, poz. 1119 ze zm.

Ustawa z dnia 5 sierpnia 2015 r. o nadzorze makroostrożnościowym nad systemem finansowym i zarzqdzaniu kryzysowym w systemie finansowym, Dz. U. 2015, poz. 1513.

\section{Orzecznictwo sądów:}

Wyrok z dnia 1 grudnia 1998 r. przepisy przyjmujace Marszatkowi Sejmu prawo nadania statutu Najwyższej Izbie Kontroli oraz powołania wiceprezesów i członków Kolegium NIK, sygn. K 21/98, OTK ZU, nr 7/2000.

Wyrok TK z dnia 28 czerwca 2000 r. prawo organów Narodowego Banku Polskiego do wydawania powszechnie obowiqzujacych uchwat, sygn. K 25/99, OTK $\mathrm{ZU}, \mathrm{nr} 5 / 2000$.

Wyrok TK z dnia 21 czerwca 2011 r. w sprawie statusu pracowników Urzędu Komisji Nadzoru Finansowego, syg. K2/09, OTK ZU, nr 5A/2011.

\section{Dokumenty i materiały:}

Biuro Analiz Sejmowych, opinia zlecona o projekcie ustawy o nadzorze nad rynkiem finansowym, druk sejmowy nr 654, (2006) Warszawa, 4 lipca.

Ogólnopolska Konferencja Naukowa „Komisja Nadzoru Finansowego - status prawny i zadania nadzoru finansowego w Polsce" (2010), KNF, 25 luty.

Opinia Europejskiego Banku Centralnego z dnia 18 lutego 2014 r. w sprawie nadzoru nad systemem finansowym (CON/2014/18).

Projekt ustawy o nadzorze makroostrożnościowym z dnia 23 kwietnia 2014 r. 
Projekt ustawy o nadzorze makroostrożnościowym z dnia 3 stycznia 2014 r.

Projekt rządowy ustawy o nadzorze nad rynkiem finansowym wraz z projektami aktów wykonawczych (2006) druk sejmowy nr 654, Warszawa, 7 czerwca.

\section{Publikacje zwarte:}

Daniluk D. (1996), Regulacje i nadzór bankowy w Polsce, BMiB, Warszawa.

Fojcik-Mastalska E. (red.), (2009), Prawo bankowe, UWr, Wrocław.

Karpusia P., Węcławski J. (red.), (2003), Rynek finansowy: instytucje, strategie, instrumenty, UMCS, Lublin.

Kraś I. (2013), Rola Narodowego Banku Polskiego w Polityce gospodarczej Polski w latach 1987-2010, AJD, Częstochowa.

Lipowicz I. (2015), Prawo administracyjne. Zagadnienia podstawowe, Wolters Kluwer business, Warszawa.

Matthews K., Thompson J. (2007), Ekonomika bankowości, PWE, Warszawa.

Nadolska A. (2011), Status prawny Komisji Nadzoru Finansowego, „Annales Universitatis Mariae Curie-Skłodowska”, vol. XLV.

Nadolska A. (2014), Komisja Nadzoru Finansowego w nowej instytucjonalnej architekturze europejskiego nadzoru finansowego, Wolters Kluwer, Warszawa.

Nadzór bankowy 1989-2006 (2007), NBP, Warszawa.

Pietrzak B., Polański Z. (red.), (2000), System finansowy w Polsce. Lata dziewięćdziesiate, PWN, Warszawa.

Pietrzak B., Polański Z., Woźniak B. (red.), (2008), System finansowy w Polsce, PWN, Warszawa.

Szczepańska O., Sotomska-Krzysztofik P., Pawliszyn M., Pawlikowski A. (2004), Instytucjonalne uwarunkowania stabilności finansowej na przykładzie wybranych krajów, „Materiały i Studia”, z. 173.

Wierzbowski M. (red.), (2015), Prawo administracyjne, Wolters Kluwer, Warszawa.

\section{Artykuły}

Buczyński G. (2002), Standardy kontroli Najwyższej Izby Kontroli, „Kontrola Państwowa" R. XLVIII, nr 5(286), NIK, Warszawa.

Goodhardt Ch. (2000), The Organizational Structure of Banking Supervision, FSI Ocassional Paper No. 1, BIS.

Hryckiewicz A., Pawłowska M. (2013), Czy nowy nadzór spetni swoje zadanie? Zmiany $w$ nadzorze finansowym $w$ Europie oraz ich konsekwencje dla Polski, „Materiały i Studia”, z. 289.

Matysek-Jędrych A. (2007), Struktura i modele systemu finansowego, „Bank i Kredyt" 2007, nr 11-12.

Szczepańska O., Sotomska-Krzysztofik P., Pawliszyn M., Pawlikowski A. (2004), Instytucjonalne uwarunkowania stabilności finansowej na przykładzie wybranych krajów, „Materiały i Studia”, z. 173. 
Organization of the supervision of the financial system in Poland

\section{Summary}

The aim of this paper is to analyze the work of entities supervising the Polish financial system. It opens with considerations on the issue of supervising the financial system. Next, issues connected with the evolution of financial supervision in Poland after 1989 are presented, followed by a discussion of the functioning of the Financial Supervision Authority, as the body responsible for microprudential oversight, and the Financial Stability Committee which focuses on macroprudential oversight. Finally, the author refers to the hypothesis discussed in the introduction and presents the conclusions.

Key words: financial system, microprudential oversight, macroprudential oversight, financial institutions 